\title{
Cistus $\times$ Incanus L. Pandalis Is Highly Effective Against Delta Variant of SARS-CoV-2 in Vitro
}

\author{
Jens-Martin Traeder \\ Institute of General Medicine, University of Luebeck, Lubeck, Germany
}

\section{Email address:}

traeder@posteo.de

\section{To cite this article:}

Jens-Martin Traeder. Cistus $\times$ Incanus L. Pandalis Is Highly Effective Against Delta Variant of SARS-CoV-2 in Vitro. Journal of Diseases and Medicinal Plants. Vol. 7, No. 3, 2021, pp. 82-86. doi: 10.11648/j.jdmp.20210703.13

Received: August 23, 2021; Accepted: September 3, 2021; Published: September 8, 2021

\begin{abstract}
Background: Recent studies have shown that a special extract from Cistus $x$ incanus L. Pandalis (Cystus Pandalis ${ }^{\circledR}$ extract) has proven to be effective against SARS-CoV-2 in vitro and it is likely that the extract shows to be effective against other new variants of SARS-CoV-2 like the "Indian" Delta-Variety as well. Methods: In order to verify our claim, we examined how the extract Cystus Pandalis ${ }^{\circledR}$ inhibits the cytopathic action (CPE) of the Coronavirus in a cell model with human intestinal cells (Caco-2). We incubated viruses with the extract and mixed them with the cell cultures. Result: Cystus Pandalis ${ }^{\circledR}$ extract has almost completely inhibited virus growth at concentrations greater than $100 \mu \mathrm{g} / \mathrm{ml}$. The calculated IC50 (mean inhibitory concentration) for the "Indian" Delta variant was $101 \mu \mathrm{g} / \mathrm{ml}$. Conclusion: Cistus $x$ incanus L. Pandalis extract (Cystus Pandalis ${ }^{\circledR}$ extract) is capable of preventing cell cultures from being infected by SARS-CoV-2 in-vitro. Because of its high in-vitro potency against the new variants of SARS-CoV-2, it is more than ever reasonable to use Cystus Pandalis ${ }^{\circledR}$ prophylactically in order to decrease the virus load. The development of resistance to the extract is not likely. People tolerate the extract very well. No significant side effects have been detected. Phytopharmaceuticals extraxted from Cistus $x$ incanus L. Pandalis are able to combat viral infections and can help contain future pandamics by being handed in advance profilactically.
\end{abstract}

Keywords: Cystus Pandalis ${ }^{\circledR}$, Virus Infection, SARS-CoV-2, Variants, Cistus Incanus, Delta

\section{Introduction}

In times of a global pandemic, we become aware that we are inadequately prepared against new emerging pathogens. By the time an effective antidote is finished being fully developed and ready for shipment, it takes months or normally years after a new virus had been found for the first time. During that period, the newly developed pathogen could cause a considerable amount of human casualties and reek economic havoc depending on the pathogen's characteristics.

After nearly $11 / 2$ years after the breakout of the COVID-19 pandemic, the situation hasn't changed profoundly. Just months after the first cases emerged, vaccines had started being developed and eventually rolled out to the public. Ineffective vaccines inadequate of preventing infection and transmission could cause selection pressure on the virus, resulting in the development of new variants, provided the virus is prone and tolerant towards fast mutations [1]. Due to the high error ratio of RNA-polymerases, RNA-viruses tend toward mutations [2]. From today's point of view, the newly admitted vaccines are likely to decrease in effectiveness over time and will require adjustment, causing the public to be re-vaccinated on a regular basis [3].

Previous studies have pointed out that vaccines that do not prevent transmission can create conditions in favor of the emergence of particularly virulent strains of pathogens causing even more severe disease in unvaccinated hosts [4]. The current developments - especially the appearance of the Delta variant - fit well into this picture.

In light of the current developments as well as in preparation for upcoming pandemics, it should not be the sole aim of global efforts to develop vaccines but also to seek for a prophylactic agent capable of protecting against newly formed pathogens without causing an increase in resistance. Natural products offer a wealth of effective compounds that interact with many surface structures of viruses so resistance is not expected to develop even in the long term.

\subsection{Cistus $x$ Incanus L. Pandalis}

The hoary rockrose Cistus $x$ incanus L. belongs to the genus 
of rockroses, which are widespread along the Mediterranean coast of Europe. Cistus grows as multiform shrub communities in Macchia. Due to adaptive radiation, it develops numerous variants [5]. Cistus $x$ incanus L. Pandalis is particularly well studied.

Cystus Pandalis ${ }^{\circledR}$ extract is an herbal product based on the cistus variety Cistus $\times$ incanus $\mathrm{L}$. Pandalis, which grows only in a specific area of northern Greece. Cistus $\times$ incanus $\mathrm{L}$. has anti-inflammatory, anti-ulcerogenic, antimicrobial and wound-healing properties. It has been used in traditional folk medicine since the 4th century $\mathrm{BC}$ due to these specific properties [6]. Its dense content of high polymeric polyphenols, while monomeric polyphenols account for less than $2 \%$, as well as the specific polyphenol characterize Cistus $\times$ incanus L. Pandalis [7].

\subsection{Mechanism of Action of Cistus $x$ Incanus L. Pandalis}

A large number of polyphenols have been studied with respect to their properties and antiviral activity. While the cells remain unaffected and cellular receptors are not addressed, Cystus Pandalis ${ }^{\circledR}$ extract and it's polyphenols are directed solely against the viruses, studies have shown. All these results point out that Cystus Pandalis ${ }^{\circledR}$ extract blocks the attachment of virus particles to cells, thus preventing virus entry into host cells in the first place [7].

\section{Material \& Methods}

To investigate the antiviral activity of a plant extract against SARS-CoV-2, we used a cell culture-based infection model. These studies were conducted at Goethe University (Frankfurt am Main, Germany).

The examined (Cystus Pandalis ${ }^{\circledR}$ ) extract is an aqueous dry extract of the cistus variety Cistus $x$ incanus L. Pandalis and was provided by the company Dr. Pandalis Urheimische Medizin GmbH \& Co. KG. Caco-2 cells were used as the cell line for the infection model. This specific human cell line is widely used to study SARS-CoV-2 due to its high permissiveness to coronavirus infection. Clinical SARS-CoV-2 isolates were obtained from nasopharyngeal swabs of COVID-19 patients. The strain SARS-CoV-2/Delta ("Indian" variant) was used in the experiments. Infection was performed in the following experimental set-up: SARS-CoV-2/Delta was preincubated with Cistus $x$ incanus L. Pandalis extract first before the mixture was then added to the cells. A multiplicity of infection (MOI) of 0.01 was used. Two independent technicians evaluated $48 \mathrm{~h}$ post infection the cytopathogenic effect (CPE) visually. Additionally, cell viability was measured by MTT assay. We used GraphPad Prism 6 for evaluating IC50 and CC50. The results are given as mean \pm standard deviation.

To determine how Cystus Pandalis ${ }^{\circledR}$ extract's antiviral activity works against SARS-CoV-2, a binding assay is performed. It focuses on the extent to which Cystus Pandalis ${ }^{\circledR}$ extract can interfere with the binding between the spike protein (S1) or receptor binding domain (RBD) respectively and ACE2 (according to the instructions of the supplier BPS
Bioscience, USA).

ACE2-SARS-CoV-2 Spike S1: First, the ACE2 protein is attached to a nickel-coated 96-well plate. The extract is then dissolved in PBS and this solution is afterwards incubated together with SARS-CoV-2 Spike S1 protein (BPS Bioscience 79945, lot 210721-K) labeled with biotin and added to the 96-well plate containing ACE2. Finally, the plate is treated with streptavidin-HRP and added with HRP substrate to generate chemiluminescence, which we measured using a chemiluminescence reader (luminescence measurement time: 0.1 s, Victor X5, Perkin Elmer, USA). We used Spike S1 neutralizing antibody (BPS Bioscience 100793, lot 200617) as a positive control.

ACE2-SARS-CoV-2 Spike S1 RBD: First, ACE2 protein is bound to a nickel-coated 96-well plate. The extract is then dissolved in PBS and this solution is incubated together with SARS-CoV-2 Spike S1 protein (BPS Bioscience 79936, lot 210721-K) and added to the 96-well plate containing ACE2. Finally, the plate is treated with anti-mouse Fc-HRP - a specific antibody of RBD - followed by the addition of an HRP substrate to generate chemiluminescence, which can then be measured with a chemiluminescence reader (luminescence measurement time: $0.1 \mathrm{~s}$, Victor X5, Perkin Elmer, USA). Spike S1 neutralizing antibody (BPS Bioscience 100793, lot 200617) was used as a positive control.

\section{Results}

In order to investigate at which concentration Cystus Pandalis ${ }^{\circledR}$ extract shows antiviral activity against the delta variant of SARS-CoV-2, it was focused on the extent to which the virus-induced cytopathic effect (CPE) was absent at the different test concentrations (Figure 1). We could demonstrate an antiviral efficacy of the Cystus Pandalis ${ }^{\circledR}$ extract against the Delta variant clearly. Based on these results, the IC50 value (the mean inhibitory concentration) for inhibition of virus growth by Cystus Pandalis ${ }^{\circledR}$ extract was determined. The IC50 for the delta variant is $101.3 \mu \mathrm{g} / \mathrm{ml}$. No cytotoxic effects of the extract occurred.

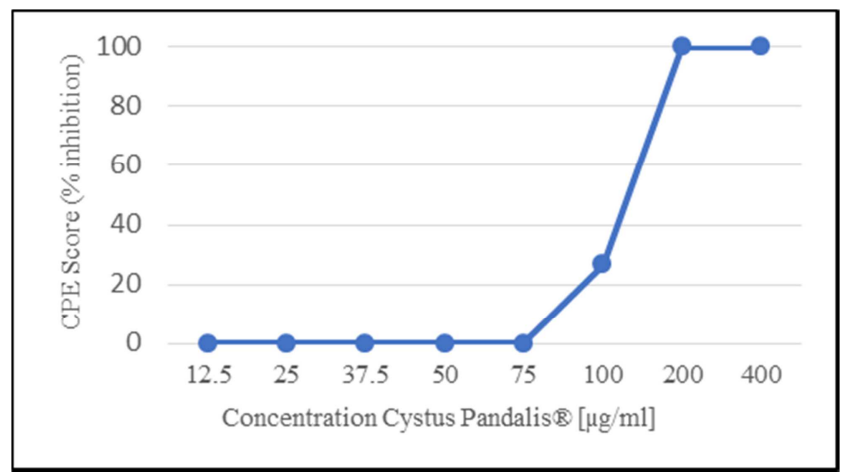

Figure 1. Concentration-dependent antiviral effects of Cystus Pandalis ${ }^{\circledR}$ extract on SARS-CoV-2-induced cytopathic effect (CPE).

Cystus Pandalis ${ }^{\circledR}$ extract reduced the binding between spike protein or receptor binding domain (RBD) and the cellular ACE2 receptor in a concentration-dependent manner. The 
extract reduced these bindings at $250 \mu \mathrm{g} / \mathrm{ml}$ by about $60 \%$ each. (Figure 2).

The required concentrations for effectiveness are exceeded by far (up to a hundredfold) when Cystus Pandalis ${ }^{\circledR}$ extract is taken orally, both in liquid form and in the form of lozenges. Properly applied, a potent effect is most likely.

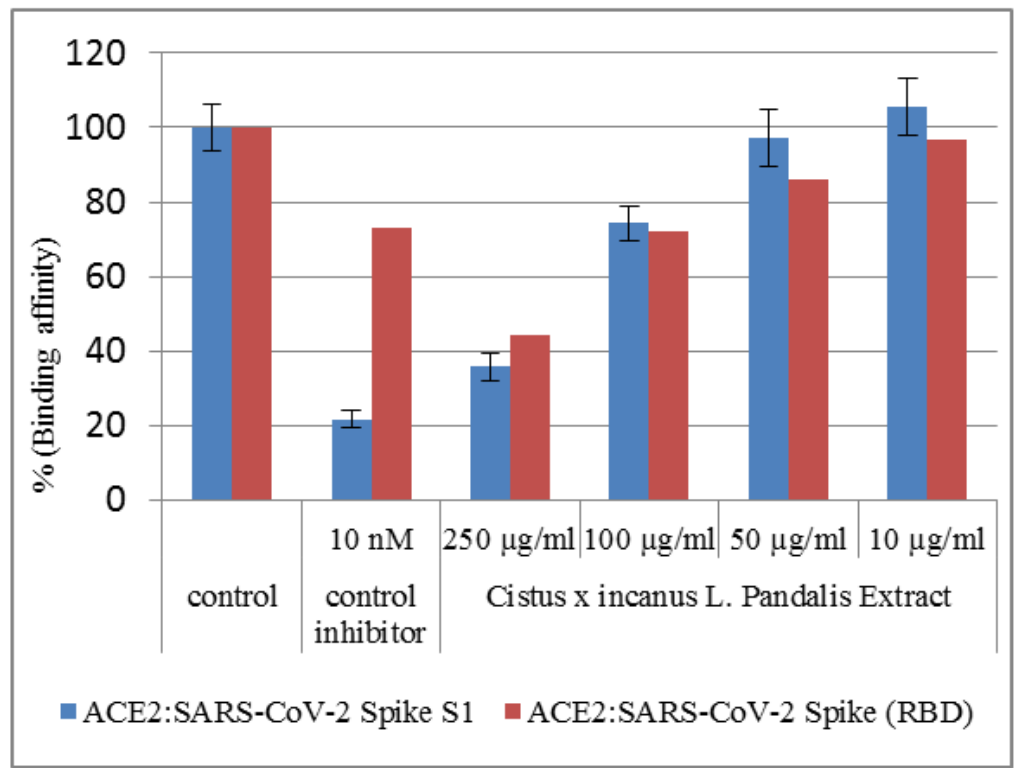

Figure 2. Effect of Cystus Pandalis ${ }^{\circledR}$ extract on the interaction between ACE2 and SARS-CoV-2 spike S1 as well as between ACE2 and SARS-CoV-2 spike receptor-binding domain (RBD). This Data represents the mean of $n=8$ (control binding was set at $100 \%$ ).

\section{Discussion}

As the results of this study show, Cystus Pandalis ${ }^{\circledR}$ extract inhibits viral replication of the delta variant of SARS-CoV-2 in a cell culture model with an IC50 of $101.3 \mu \mathrm{g} / \mathrm{ml}$. In previous studies, the IC50 was $48.9 \mu \mathrm{g} / \mathrm{ml}$ (alpha) and 45.2 $\mu \mathrm{g} / \mathrm{ml}$ (beta) in the same cell model $[9,10]$. In another cell model (Vero E6), an EC50 of $1.94 \mu \mathrm{g} / \mathrm{ml}$ was determined for the wild type (Figure 3 ). The differences in effectiveness between the wild type and the different variants are probably due to the completely different experimental setup and cell system. In conclusion: Cystus Pandalis ${ }^{\circledR}$ extract is effective against SARS-CoV-2 in alpha, beta and delta variants.

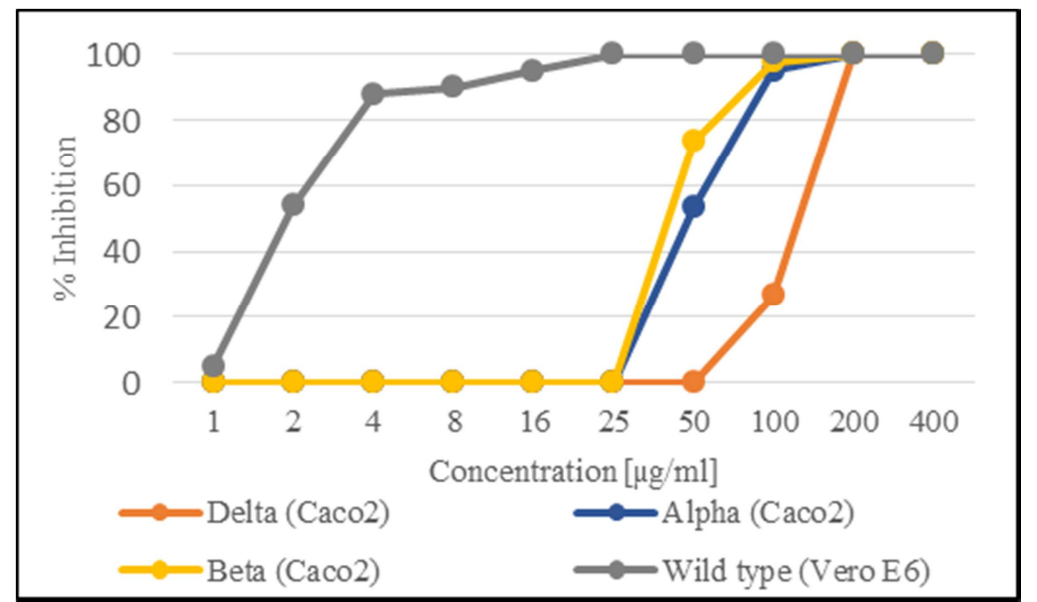

Figure 3. Concentration-dependent antiviral effects of Cystus Pandalis ${ }^{\circledR}$ extract on alpha (blue), beta (yellow), delta (orange), and wild-type (gray) variants of SARS-CoV-2.

Given the antiviral mechanism of action, this result is plausible. Based on previous studies, the extract appears to prevent viral replication while acting as an entry inhibitor, whereas the components interact primarily with viruses but not with cells $[7-10,15]$. It was not clear which of the viral proteins was the preferred target for Cystus Pandalis ${ }^{\circledR}$ extract. Other studies investigating the binding affinities of various polyphenols to the different structures of SARS-CoV-2 suggested that Cystus Pandalis ${ }^{\circledR}$ extract binds to the $\mathrm{S}$ protein (spike, membrane protein) [11]. This current study confirms this notion. In addition, Cystus Pandalis ${ }^{\circledR}$ extract affects direct binding of the receptor-binding domain (RBD) preventing SARS-CoV-2 from binding to the cellular ACE2 receptor and preventing the virus from entering the cell by this route (Figure 4). 


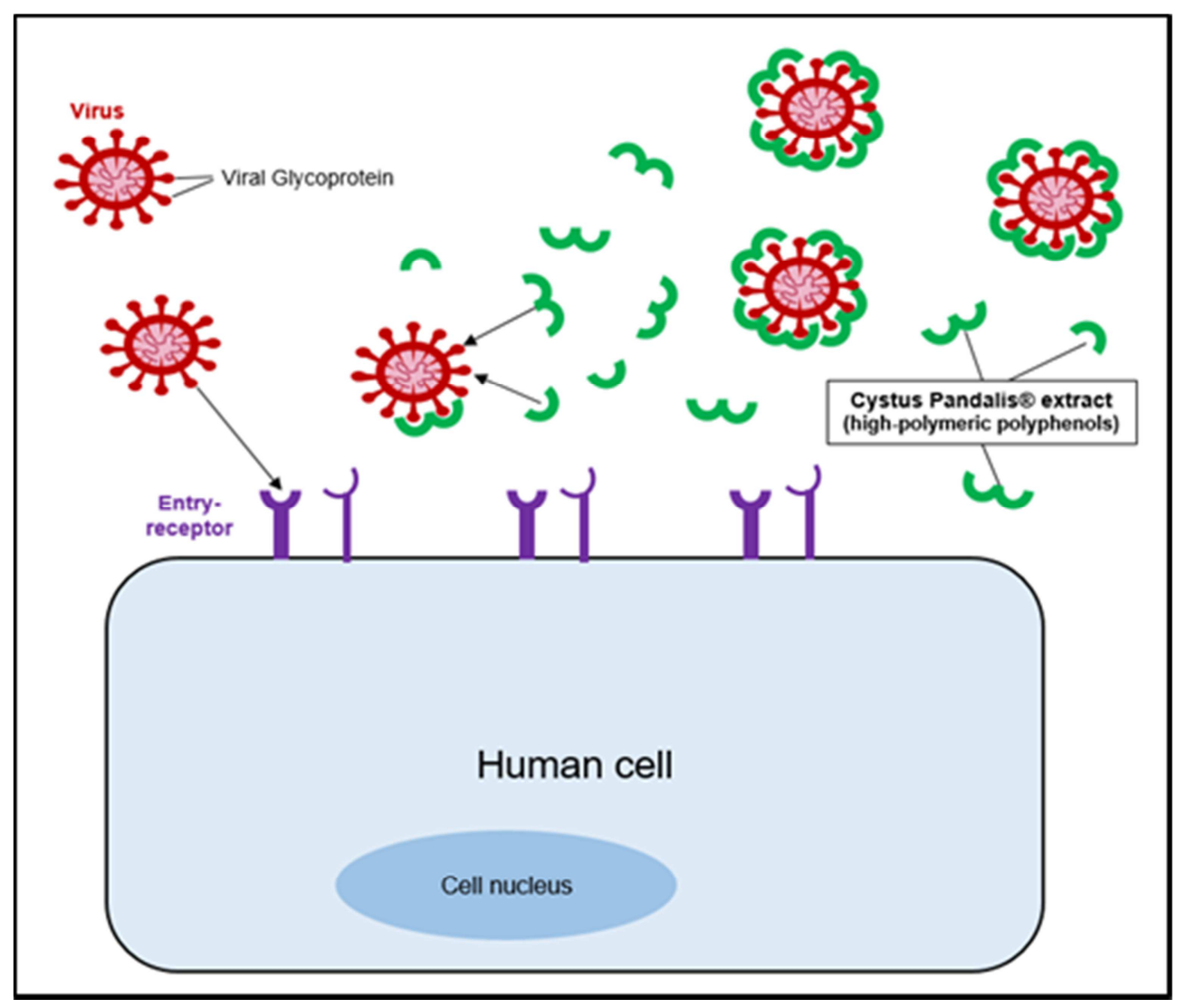

Figure 4. Mechanism of action of Cystus Pandalis ${ }^{\circledR}$ extract against SARS-CoV-2.

High polymer polyphenols in CPE (green) interact with specific viral epitopes of SARS-CoV-2 (red), enveloping the virus and thereby preventing its attachment to cellular receptors (blue/purple), thereby preventing infection of the cell (light blue).

Recent studies have shown that various polyphenols such as epigallocatechin gallate (EGCG), myricetin and quercetin interact with other surface proteins of SARS-CoV-2 in addition to the $\mathrm{S}$ protein [11]. Since these polyphenols are also present in Cystus Pandalis ${ }^{\circledR}$ extract, this mechanism would be plausible [12].

For practical application, it is also important to note: The extract is effective even when the cells were pre-incubated and the viruses were added later, as studies have pointed out. Topical application in the form of a lozenge allows the extract to develop its antiviral potential directly in the mouth and throat at the point of entry of infections. Products applying the extract from the variety Cistus $\times$ incanus L. Pandalis have been on the market for years, have been sold and used for a long time and are directly available for everyone.

Considering this and previous studies on this extract, it is sensible to use Cystus Pandalis ${ }^{\circledR}$ prophylactically against infections with SARS-CoV-2, regardless of the variant $[9,10$, $13,14]$. These promising results also suggest future usage during this current and possible upcoming viral pandemics. In addition, this herbal product shows no signs of side effects and shows overall excellent tolerability. One can assume Cell-protective effects.
It is sensible to keep in mind that many people cannot be inoculated due to medical issues, religious or personal inclinations. Moreover, there has not been an authorized vaccine available for children yet. Cystus Pandalis ${ }^{\circledR}$ extract would provide a natural and effective alternative option available for everyone to combat this current and possible further occurring mutations. It would be a truly wasted opportunity if herbal active ingredients were not considered in science as well as in politics.

\section{Summary}

Recent studies have shown that a herbal extract (Cystus Pandalis $^{\circledR}$ extract) has proven to be effective against SARS-CoV-2 an some of its variants (Alpha, Beta) in vitro. It was likely that the extract shows to be effective against the new variants of SARS-CoV-2 like the "Indian" Delta-Variety as well. We examined whether the extract Cystus Pandalis ${ }^{\circledR}$ inhibits the cytopathic action (CPE) of the Coronavirus in a cell model. In this cell model the herbal extract is capable of preventing cell cultures from being infected by SARS-CoV-2 in-vitro.

The development of resistance to the extract is not likely. People tolerate the extract very well. No significant side effects have been detected.

Because of its high in-vitro potency against the new variants of SARS-CoV-2, it is more than ever reasonable to use Cystus Pandalis ${ }^{\circledR}$ prophylactically in order to decrease the virus load. 


\section{Conflict of Interest}

The author declares no conflicts of interest. There are no influences on the design of the study, nor the collection, analysis, or interpretation of the data, the writing of the manuscript, or the decision to publish the results.

\section{References}

[1] DAZ: Mutanten und Virusevolution - Kann Impfen Resistenzen fördern? 31.03.2021 https://www.deutsche-apotheker-zeitung.de/news/artikel/2021/ 03/31/kann-impfen-resistenzen-foerdern/chapter:1.

[2] Sanjuán R, Nebot MR, Chirico N, Mansky LM, Belshaw R.: Viral mutation rates. J Virol. 2010 Oct; 84 (19): 9733-48. doi: 10.1128/JVI.00694-10. Epub 2010 Jul 21.

[3] Jo, W. K., Drosten, C., \& Drexler, J.: The evolutionary dynamics of endemic human coronaviruses, Virus Evolution, Volume 7, Issue 1, January 2021, https://doi.org/10.1093/ve/veab020.

[4] Read AF, Baigent SJ, Powers C, Kgosana LB, Blackwell L, et al.: Imperfect Vaccination Can Enhance the Transmission of Highly Virulent Pathogens. PLOS Biology 13 (7): e1002198. https://doi.org/10.1371/journal.pbio.1002198 (2015).

[5] Pott R: Polymorphismus bei Cistrosen: Welche Varietät ist als Heilmittel tauglich? KFN-Pressekonferenz, Vortrag, 8. 11. 2006.

[6] Petereit F.: Polyphenolische Inhaltsstoffe und Untersuchungen zur entzündungshemmenden Aktivität der traditionellen Arzneipflanze Cistus incanus L. (Cistaceae). Dissertation, Universität Münster, 1992.

[7] Ehrhardt C, Hrincius ER, Korte V, Mazur I, Droebner K, et al.: A polyphenol rich plant extract, CYSTUS052, exerts anti influenza virus activity in cell culture without toxic side effects or the tendency to induce viral resistance. Antiviral research 2007, 76 (1), 38-47. doi: 10.1016/j.antiviral.2007.05.002.
[8] Rebensburg S, Helfer M, Schneider M, Koppensteiner H, Eberle $\mathrm{J}$, et al.: Potent in vitro antiviral activity of Cistus incanus extract against HIV and Filoviruses targets viral envelope proteins. Scientific reports 2016, 6, 20394. doi: 10.1038/srep20394.

[9] Traeder JM: Antivirale Eigenschaften des Extrakts aus Cistus $\times$ incanus L. Pandalis auch bei SARS-CoV-2 in vitro nachgewiesen. Zeitschrift für Phytotherapie 2021; 42 (03): 121-126, DOI: 10.1055/a-1302-6097.

[10] Traeder JM: Extract from Cistus $\times$ Incanus L. Pandalis also Effective against "British" Alpha (B. 1.1.7) and "South African" Beta (B. 1.351) SARS-CoV-2 Variants, Journal of Diseases and Medicinal Plants. Vol. 7, No. 2, 2021, pp. 44-47. doi: 10.11648/j.jdmp.20210702.13.

[11] Mhatre S, Srivastava T, Naik S, Patravale V.: Antiviral activity of green tea and black tea polyphenols in prophylaxis and treatment of COVID-19: A review [published online ahead of print, 2020 Jul 17]. Phytomedicine. 2020; 153286.

[12] Riehle P: Phenolische Inhaltsstoffe in C. incanus Tee Charakterisierung und Stabilität innerhalb der Teezubereitung. Dissertation Universität Hamburg (2014).

[13] Kalus U, Grigorov A, Kadecki O, Jansen JP, Kiesewetter H, et al.: Cistus incanus (CYSTUS052) for treating patients with infection of the upper respiratory tract: a prospective, randomised, placebo-controlled clinical study. Antiviral $\begin{array}{lllll}\text { research 2009, } 84 & \text { (3), 267-271. doi: }\end{array}$ 10.1016/j.antiviral.2009.10.001.

[14] Kalus U, Kiesewetter H, Radtke H.: Effect of CYSTUS052 and green tea on subjective symptoms in patients with infection of the upper respiratory tract. Phytother Res. 2010 Jan; 24 (1): 96-100. doi: 10.1002/ptr.2876. PMID: 19444821.

[15] Traeder JM: Zistrosenextrakt zur Prophylaxe. Erfahrungsheilkunde 2021; 70: 204-208. Thieme, Stuttgart. 